\title{
BATAS TANGGUNG JAWAB HUKUM DAN ETIS ATAS PERILAKU TERCELA ADVOKAT DALAM PERSIDANGAN
}

\author{
${ }^{1}$ Gladwin Lukman, ${ }^{2}$ Findy, ${ }^{3}$ Indra Kho, ${ }^{4}$ Edric Victori \\ Etika profesi, Fakultas Hukum, Universitas Tarumanagara \\ Jl tanjung gedong 1 No. 30 rt2/rw16, tomang grogol petamburan, jakarta barat. 11440 \\ Jakarta \\ 1'Gladwinlukman@gmail.com, ${ }^{2}$ Findy135@gmail.com, ${ }^{3}$ kho_indra30@yahoo.com, \\ ${ }^{4}$ Edricvictori23@yahoo.com
}

\begin{abstract}
Advocates play an important role in litigation and proceedings before the Court because advocates are equipped with knowledge and expertise in the field of law and can be seen that the implementation of the advocate's role in providing legal services to clients. The writing of this article is based on normative juridical legal research with an approach method that uses a positivist legis conception. The analytical method used is descriptive qualitative analysis which presents a study of the data obtained from the research object. The role of advocates is in providing legal services not only to one level but can be carried out starting from the District Court, the High Court, and to the level of the Supreme Court. The implementation of the advocate's role in providing legal services to clients depends on the power of attorney to the extent to which the power is given. In carrying out his profession as an Advocate has the duties, rights and responsibilities. Regarding the legal and ethical liability limits of the disgraceful conduct carried out by lawyers in the trials contained in the Advocate Code of Ethics which has clearly regulated the related sanctions that can be imposed, if there is a violation of the Advocate Code of Ethics, precisely in Article 16.
\end{abstract}

Keywords: Advocate; Ethical; Despicable Behavior; Legal Liability

Abstrak, Di ranah hukum, peran advokat sangatlah penting, yaitu yang berkaitan dengan berperkara di hadapan pengadilan karena kemahiran serta wawsasan di bidang hukum sebagai bekal utamanya dan dapat diperhatikan peranan seorang advokat tentang memberikan jasa hukum pada klien. Penulisan artikel ini didasarkan pada penelitian hukum yuridis normatif dengan metode pendekatan yang menggunakan konsepsi legis positivis. Adapun metode analisis yang digunakan adalah analisis deskriptif kualitatif yaitu menyajikan kajian pada datadata yang diperoleh dari objek penelitian. Berhubungan dengan pemberian jasa hukum peranan advokat tak terbatas pada satu tingkat saja, tapi bisa dimulai dari tingkat PN (pengadilan Negeri), Pengadilan Tinggi, bahkan sampai tingkat Mahkamah Agung. Pelaksanaan peranan advokat dalam memberikan jasa hukum pada klien tergantung dari surat kuasa sejauh mana kuasa diberikan. Di dalam menjalankan profesinya sebagai seorang Advokat mempunyai tugas, hak dan tanggungjawabnya. Terkait batas tanggungjawab hukum dan etis perilaku tercela yang dilakukan Advokat dalam persidangan terdapat dalam Kode Etik Advokat yang telah secara jelas mengatur terkait sanksi-sanksi yang dapat dijatuhkan, apabila terjadi pelanggaran terhadap Kode Etik Advokat, tepatnya dalam Pasal 16.

Kata kund: Advokat; Etis; Perilaku Tercela; Tanggung Jawab Hukum

\section{Pendahuluan}

Indonesia adalah suatu Negara yang berlandaskan Hukum. Hal tersebut bisa di lihat berdasarkan penjelasan dalam Pasal 1 ayat (3) Undang-undang Dasar Negara Republik 
Indonesia 1945. Hukum tidak lepas dari kehidupan manusia dan perkembangan sosial tindakan manusia. Hal ini dikarenakan manusia dalam proses berinteraksi dengan sesamanya seringkali mendahulukan atau mempertahankan kepentingannya daripada kepentingan orang lain dengan melanggar atau mengabaikan aturan yang seharusnya ditaatinya. Di mana dalam hal ini kepentingan merupakan suatu kebutuhan manusia, yang mana kebutuhan manusia sendiri terdiri dari kebutuhan biologis dan kebutuhan sosial, dalam hal ini yang dimaksud dengan kebutuhan sosial adalah status sosial, peranan sosial dan rasa aman.

Rasa aman merupakan kebutuhan manusia yang penting, di mana hal ini didukung oleh teori hierarki kebutuhan manusia yang menunjukkan bahwa rasa aman berada pada tingkatan kedua di bawah kebutuhan dasar manusia seperti sandang, pangan dan papan. Rasa aman itu sendiri merupakan kebebasan yang memiliki batasan. Menurut Maslow dalam Goble, kebebasan yang memiliki batas sesungguhnya diperlukan untuk perkembangan manusia ke arah penyesuaian yang baik ${ }^{1}$. Ini menunjukkan bahwa sesungguhnya manusia butuh suatu aturan untuk membatasi perilakunya. Salah satu wujud konkret aturan tersebut adalah Hukum.

Indonesia sebagai Negara hukum menjamin atau memberikan rasa aman kepada seluruh rakyatnya sebagaimana yang bisa kita lihat dalam pembukaan UUD 1945 yang bunyinya "Pemerintah dan Negara Indonesia yang melindungi segenap bangsa Indonesia dan seluruh tumpah darah Indonesia...". Manusia harus mentaati aturan karena aturan memberi arahan atau petunjuk bagaimana manusia harus bertindak dan berperilaku. Tanpa disadari atau bahkan dengan sadar, manusia sudah dipengaruhi oleh peraturanperaturan dalam kehidupan bermasyarakat yang secara tidak langsung maupun langsung telah mengekang kehendak bebas manusia, kemudian ini mendasari atau melatarbelakangi manusia untuk tidak melakukan sesuatu tanpa ada dasar yang benar.

Oleh sebab itu, timbulah konsekuensi adanya lembaga peradilan karena itu merupakan syarat bagi negara hukum. Peradilan menurut Sjachran Basah adalah segala sesuatu yang berkaitan dengan tugas dalam memututs perkara dengan menerapkan hukum, menemukan hukum in concerto dalam mempertahankan dan menjamin ditaatinya hukum formal ${ }^{2}$. Lembaga ini sendiri merupakan sarana bagi masyarakat untuk menuntut hak dan kewajiban agar hukum dan keadilan dapat ditegakkan. Dengan adanya perubahan dan kemajuan zaman, peran peradilan menjadi vital guna mencapai ketertiban hukum.

Advokat berasaskan pada kehormatan serta karakter yang memegang erat sikap mandiri, jujur, rahasia dan terbuka, yang mana pekerjaan ini dianggap terpandang yang segala bentuk prosesnya berada dibawah kode etik, Undang-undang, dan mempunyai kebebasan. Profesi ini merupakan salah satu penegak hukum yang setingkat dengan

\footnotetext{
${ }^{1}$ Goble, Mazhab Ketiga, Psikologi Humanistik Abraham Maslow, (Kanisius, 1987), hlm 73.

${ }^{2}$ Sjachran Basah, Mengenal Peradilan di Indonesia, (Jakarta: Raja Grafindo Persada, 1995), hlm 9.
} 
penegak hukum lain, untuk itu, perlu adanya keharusan untuk menghargai teman sejawat juga yang lainnya. ${ }^{3}$

Advokat, menurut Pasal 1 Angka 1 Undang-Undang Nomor 18 Tahun 2003 tentang Advokat, didefinisikan sebagai "orang yang berprofesi memberi jasa hukum, baik di dalam maupun di luar pengadilan yang memenuhi persyaratan berdasarkan ketentuan Undang-Undang ini." " Dalam Kode Etik Advokat, diterangkan bahwa:

"Advokat adalah orang yang berpraktek memberi jasa hukum, baik dalam maupun di luar pengadilan yang memenuhi persyaratan berdasarkan undang-undang yang berlaku, baik sebagai Advokat, Pengacara, Penasehat Hukum, Pengacara praktek ataupun sebagai konsultan hukum."5

Kasus Perilaku tercela dalam persidangan Advokat pertama kali muncul di Indonesia terjadi pada saat persidangan H.R. Dharsono anggota Petisi 50 dengan Advokatnya Adnan Buyung Nasution. Adnan Buyung Nasution dinyatakan telah melakukan perbuatan tercela dalam persidangan (Contempt of Court) oleh Ketua Pengadilan Negeri Jakarta Pusat, karena advokat tersebut dianggap menghina pengadilan dengan aksi protesnya ketika mengadakan pembelaan dalam perkara H.R Dharsono atas dakwaan melakukan tindak pidana subversi. Adnan Buyung Nasutian dianggap membuat kegaduhan di pengadilan yang mengakibatkan advokat itu mendapat teguran, bahkan pada proses selanjutnya Dewan Kehormatan IKADIN telah menyatakan perbuatan advokat itu telah melanggar kode etik advokat. Tindakan itu ditindaklanjuti dengan dikeluarkannya Surat Keputusan Menteri Kehakiman RI yang menghentikan acara profesinya selama 1 (satu) tahun. ${ }^{6}$ Hal tersebut melanggar ketentuan yang tercantum dalam Kode Etik Advokat. Secara spesifik, yaitu pada Pasal 3 Huruf h, yang menyatakan bahwa "Advokat dalam menjalankan profesinya harus bersikap sopan terhadap semua pihak namun wajib mempertahankan hak dan martabat advokat."7

Kedudukan, tugas, dan wewenang para penegak hukum tersebut telah diatur sedemikian rupa dalam undang-undang tersendiri, antara lain Undang-Undang No. 2 Tahun 2002 tentang Kepolisian Negara Republik Indonesia (POLRI), Undang-Undang No. 16 Tahun 2004 tentang Kejaksaan Republik Indonesia, dan Undang-Undang No. 18 Tahun 2003 tentang Advokat. Sedangkan untuk kedudukan hakim diatur dalam beberapa perundang-undangan, diantaranya Undang-Undang No. 48 Tahun 2009 tentang Kekuasaan Kehakiman, UndangUndang No. 5 Tahun 2004 tentang Perubahan Atas Undang-Undang No. 14 Tahun 1985 tentang Mahkamah Agung, Undang-Undang No. 24 Tahun 2003 tentang Mahkamah Konstitusi, dan Undang-Undang No. No. 22 Tahun 2004 tentang Komisi Yudisial.

3 Kode Etik Advokat, Pembukaan (paragraf 2).

${ }^{4}$ Undang-Undang Nomor 18 Tahun 2003 tentang Advokat (Lembaran Negara Republik Indonesia Tahun 2003 Nomor 49, Tambahan Lembaran Negara Republik Indonesia Nomor 4288), Pasal 1 Angka 1.

${ }^{5}$ Kode Etik Advokat, Op.Cit., Pasal 1 Huruf a.

${ }^{6}$ Majalah Tempo, Maret 1986, hlm. 66.

7 Ibid., Pasal 3 Huruf h 
Pekerjaan para penegak hukum termasuk ke dalam profesi dimana dilakukan berdasarkan keahlian khusus dan secara bertanggungjawab, maka bagi setiap lembaga penegak hukum dibentuk suatu kode etik profesi yang mengikat setiap anggotanya. Pembentukan kode etik profesi ini dimaksudkan untuk menjaga nama baik institusi dan menjaga perilaku anggota dari institusi terkait dalam melaksanakan profesi mereka. Secara langsung, kode etik profesi dapat berfungsi sebagai sarana kontrol sosial, berfungsi mencegah pengawasan atau campur tangan yang dilakukan pemerintah atau masyarakat melalui beberapa agen atau pelaksananya, dan berfungsi untuk pengembangan patokan kehendak yang lebih tinggi. Secara tidak langsung, adanya kode etik profesi ini juga bertujuan untuk melindungi martabat peradilan dari adanya rongrongan pihak yang terlibat dalam proses pengadilan, maupun dari pihak luar, misalnya media massa, atau yang biasa dikenal dengan Contempt of Court. ${ }^{8}$

Pengaturan mengenai perbuatan tercela dalam persidangan (Contempt of Court) terhadap di Indonesia dapat dilihat dari diundangkannya Undang-undang No. 14 Tahun 1985 tentang Mahkamah Agung yang telah diperbaharui dan disempurnakan dengan UU RI No 3 Tahun 2009 terutama penjelasan umum butir 4 yang mengatakan bahwasannya pengatur berupa UU terhadap tindakan, ucapan maupun sikap melenyepkan wibawa atau membuat sesuatu menjadi rendah wibawanya, yakni martabat dan kehormatan.

Berdasarkan penjelasan diatas bisa dipahami bahwasannya pada waktu dicanangkannya Undang-undang No. 14 Tahun 1985 ada suasana yang tak begitu mendukung terkait implementasi pengadilan di Indonesia yang melakukan tuntutan akan ketetapan yang distingtif pada proses peradialn. Para hakim menanggapi hal ini dengan melakukan pengajuan opsi atau saran tentang diperlukannya perundangan atau aturan khusus yang menjamin pelindungan pada seluruh badan hukum dalam mengemban tugas. Di kalangan tertentu usulan ini diterima, karena pada dasarnya penjaminan hukum terhadap hakim akan memunnculkan hasil serta kualitas yang maksimal. Perlu adanya deterrminasi khusus hingga kebebasan serta kemerdekaan hakim dalam bertugas terjamin, menurut kalangan tersebut. Gangguan maupun ancaman menurut para hakim selama ini menghalangi mereka dalam bertugas. Sehingga tidak jarang hakim merasa khawatir.

Lalu ada juga yang berpendapat bahwasannya determinasi khusus terkait pidana pada peradilan ini semata-mata hanya untuk melindungi hakim sebagai pihak yang memiliki peran tertinggi dalam proses peradilan. Anggapan dari kalangan ini yakni bahwa hal tersebut adalah sebuah kritik serta reaksi yang dikemukakan untuk pejabat peradilan serta peradilan sendiri, yang mana kaduanya menanggapi hal ini dengan "amarah". Sedangkan kalangan ini melontarkan kritikan berdasarkan fakta kebobrokan peradilan serta pejabatnya di Indonesia, yang hingga detik ini menurut kalangan ini belum ada upaya perbaikan basis berkaitan dengan kebobrokan tersebut.

Sebagian dari kalangan-kalangan itu menyatakan dukungan pada argumen para hakim dengan alasan kelayakan perlindungan dalam bertugas akan menentukan kualitas

8 E. Sumaryono, Etika Profesi Hukum: Norma-Norma Bagi Penegak Hukum, cet. 1 (Yogyakarta: Kanisius, 1995), hlm. 35-36. 
hasil dan kinerja. Perlu adanya deterrminasi khusus hingga kebebasan serta kemerdekaan hakim dalam bertugas terjamin, menurut kalangan tersebut. ${ }^{9}$ Gangguan maupun ancaman menurut para hakim selama ini menghalangi mereka dalam bertugas. Sehingga tidak jarang hakim merasa khawatir. Kemudian berdasarkan seminar tentang perilaku tercela dalam persidangan yang diselenggarakan Ikatan Hakim Indonesia (IKAHI) pada Maret 1987, Hukum Online, 19 Maret 2005, "Diusulkan Undang-undang Contempt Of Court Untuk Lindungi Hakim". Menurut beberapa pihak aturan ini sebenarnya telah ada dalam perundang-undangan, meskipun penyebutannya tidak sama, tidak disebut sebagai Contempt Of Court. ${ }^{10}$

Dari berbagai permasalahan yang ada, dapat diidentifikasikan masalah yaitu bagaimanakah peran dan fungsi dalam pelanggaran Kode Etik Advokat? dan bagaimana batas tanggungjawab hukum dan etis Advokat yang melakukan perilaku tercela dalam persidangan?

\section{Metode Penelitian}

Penulisan artikel ini didasarkan pada penelitian hukum yuridis normatif dengan metode pendekatan yang menggunakan konsepsi legis positivis. ${ }^{11}$ Adapun metode analisis yang digunakan adalah analisis deskriptif kualitatif, yaitu menyajikan kajian pada datadata yang diperoleh dari objek penelitian. Suatu penelitian deskriptif dimaksudkan untuk memberikan data yang seteliti mungkin tentang manusia, keadaan atau gejala-gejala lainnya. ${ }^{12}$ Di sisi lain, buku juga sebagai penunjang penelitian ini dari segi referensi. Pada dasarnya penulisan artikel ini menggunakan metode penelitian secara yuridis normatif atau yang telah diatur dalam peraturan perundangan di Indonesia.

\section{Pembahasan}

\section{Peran dan Fungsi Dalam Pelanggaran Kode Etik Advokat}

Advokat merupakan peristilahan yang cukup lama, datang lebih dulu dibandingkan dengan peristilahan penasehat hukum mauun badan hukum. Tak diragukan lagi mengistilahkannya sebagai bantuan hukum maupun badan hukum lebih relevan dibanding istilah pembela, karena hanya mendampingi terdakwa maupun tersangka pada pemeriksaan. ${ }^{13}$ Di masyarakat, pada beberapa kalangan, istilah bantuan hukum, penasehat hukum, pengacara sangatlah populer, yang mana pengartian kata tersebut lebih mudah dipahami, karna memang istilah yang dipakai cukup familiar.

Pengertian advokat sendiri yaitu profesi mamndiri, bebas serta bertanggung jawab pada urusan penegakkan hukum yang memang perannya sebagai penegak hukum dan

9 Syaputra, M.Y.A.,"Penafsiran Hukum oleh Hakim Mahkamah Konstitusi, Mercatoria”, 4 (2): 72-85 Tahun 2011.

${ }^{10}$ Ibid.

11 Ronny Hantijo Soemitro, Metode Penelitian dan Jurimetri, (Jakarta: Penerbit Ghalia Indonesia, 1990), hlm, 13..

${ }^{12}$ Soejono, Soekanto, Pengantar Penelitian Hukum (Jakarta, 2007), hlm. 10

${ }^{13}$ Andi Hamzah, Hukum Acara Pidana Indonesia, Sinar Grafika, Jakarta, 2004. hlm. 86. 
mendapat penjaminan undang-undang. Jadi, advokat juga mempunyai hak kewajiban serta tanggung jawab sebagaiman diatur dalam undang-undang. Pasal 17 UU tahun 2003 No. 18 tentang advokat, memberikan hak kepada advokat dalam membela klien, yakni hak pemerolehan informasi, dokumen data atau lainnya, dari kepemerintahaan maupun pihak lain yang dibutuhkan dalam rangka membela klien dengan berdasa pada aturan Undang-Undang. ${ }^{14}$

Peran penting seorang advokat yaitu berkaitan dengan berperkara di hadapan pengadilan karena kemahiran serta wawsasan di bidang hukum sebagai bekal utamanya dan dapat diperhatikan peranan seorang advokat tentang memberikan jasa hukum pada klien. Dalam pemberian jasa hukum peran advokat tidak hanya satu tingkat saja, bahkan dari tingkat Pengadilan Negeri sampai pada Mahkamah Agung. Pemberian jasa hukum oleh advokat juga ditentukan surat kuasa yang didapatnya. Hak, kewajiban dan tanggung jawab advokat diatur dalam Pasal 14 s/d 20 Undang-Undang Nomor 18 Tahun 2003. Tugas Advokat adalah sebagai berikut: ${ }^{15}$

a. Mendampingi

b. Memberi konsultasi hukum

c. Menjalankan kuasa

d. Membela dan melaksanakan tindakan hukum lain bagi kepentingan klien

e. mewakili

f. Memberi bantuan hukum

Undang-undang juga mengatur kewajiban para advokat, terutama terkait kepentingan klien, seperti berikut ini :

a. Advokat tak membedakan klien berdasar keturunan, latar belakang sosial budaya, agama, ras suku dan lainnya.

b. Advokat tidak dapat diidentikan dengan kliennya dalam membela perkara klien oleh pihak yang berwenang dan/atau masyarakat;

c. Advokat harus merahasiakan setiap informasi yang didapat dan diketahuinya dari klien berkaitan dengan profesi, kecuali ditentukan lain oleh undangundang;

d. Advokat wajib memberi bantuan hukum secara cuma-cuma kepada pencari keadilan yang tidak mampu;

e. Advokat wajib untuk tunduk dan patuh terhadap kode etik provesi advokat;

f. Advokat berhak atas kerahasiaan hubungannya dengan klien termasuk perlindungan atas berkas dan dokumennya terhadap penyitaan dan pemeriksaan dan perlindungan terhadap penyadapan atas komunikasi elektronik advokat;

${ }^{14}$ Denny Kailimang, Mantapkan Persatuan dan Profesionalisme Advokat Sebagai Penegak Hukum dan Profesi Terhormat, Makalah, disampaikan pada Rakernas XII AAI, Pontianak, 18-19 Mei 2007. hlm. 4.

${ }^{15}$ Undang-Undang Nomor 18 Tahun 2003 tentang Advokat (Lembaran Negara Republik Indonesia Tahun 2003 Nomor 49, Tambahan Lembaran Negara Republik Indonesia Nomor 4288), Pasal 4 Angka 2 Poin ke-5. 
g. Advokat berhak menerima honorarium atas jasa hukum yang telah diberikan kepada Kliennya

Berdasarkan poin-poin tentang tugas dan kewajiban Advokat terutama terkait kepentingan klien dapat dianalisa bahwa profesi advokat memang merupakan suatu profesi yang terhormat (officium nobile), yang berarti di dalamnya terkandung kewajiban mulai dalam pelaksanaan pekerjaan. Advokat mengabdikan dirinya kepada kepentingan masyarakat dan demi penegakan hukum yang berdasarkan kepada keadilan, serta turut menegakkan hak-hak asasi manusia. Di samping itu, advokat bebas dalam membela, tidak terikat pada perintah kliennya dan tidak pandang bulu terhadap terhadap kasus yang dibelanya. Dalam membela kliennya advokat tidak boleh melanggar aturan hukum yang berlaku. Tidak boleh melanggar prinsip moral, serta tidak boleh merugikan kepentingan orang lain.

Advokat berkewajiban memberikan bantuan hukum berupa jasa hukum yang berupa menjadi pendamping, pemberi nasehat hukum, menjadi kuasa hukum untuk dan atas nama kliennya, atau dapat menjadi mediator bagi para pihak yang bersengketa tentang suatu perkara, baik yang berkaitan dengan perkara pidana, perdata, maupun tata usaha negara. Ia juga dapat menjadi fasilitator dalam mencari kebenaran dan menegakan keadilan untuk membela hak asasi manusia serta memberikan pembelaan hukum yang bebas dan mandiri. Dan dibalik pekerjaan profesionalnya yang menerima profit atau lawyer fee, tidak melupakan asas kemnusiaan yang mulia yaitu pro-bono atau bantuan hukum Cuma-cuma sebagaimana diamanatkan dalam Undang-Undang Nomor 16 Tahun 2011 Tentang Bantuan Hukum dan Peraturan Pemerintah Republik Indonesia Nomor 83 Tahun 2008 Tentang Persyaratan Dan Tata Cara Pemberian Bantuan Hukum Secara Cuma-Cuma .

Advokat merupakan salah satu penegak hukum yang bertugas memberikan bantuan hukum atau jasa hukum kepada masyarakat atau klien yang menghadapi masalah hukum yang keberadaannya sangat dibutuhkan oleh masyarakat. Advokat mengandung tugas, kewajiban, dan tanggung jawab yang luhur, baik terhadap diri sendiri, klien, pengadilan, dan Tuhan, serta demi tegaknya keadilan dan kebenaran. Dalam sumpahnya, advokat bersumpah tidak akan berbuat palsu atau membuat kepalsuan, baik di dalam maupun di luar pengadilan. Sebagai pekerjaan bermartabat Advokat karenanya harus mampu melibatkan diri leih tinggi dengan aparat penegak hukum, dasar filosofis, asas-asas, teoriteori da tentunya norma-norma hukum dan hampir semua aspek harus dikuasai. Jadi sangat keliru jika Advokat dikatakan membela orang salah karena membela hak hukum termasuk Hak Asasi Manusia seseorang yang wajib dibela sebagaimana diatur dalam Pasal 28 D Undang-undang Dasar, Konvenan Hak Sipil dan Politik, Undang-Undang Nomor 16 Tahun 2011 Tentang Bantuan Hukum, Pasal 54 Kitab Undag-Undang Hukum Acara Pidana.

\section{Batas Tanggungjawab Hukum dan Etis Perilaku Tercela Advokat Dalam Persidangan}


Menjadi seorang advokat merupakan pekrjaan yang luhur, yang mana perannya dalam penegakkan hukum sangatlah penting, bahkan kadang kala tak seperti yang dibayangkan, kadang advokat menerima tekanan-tekanan dari klien, yang bahkan sampai memngaruhi perilakunya.

Terkait kasus Adnan Buyung Nasution dinyatakan telah melakukan contempt of court oleh Ketua Pengadilan Negeri Jakarta Pusat, dikarenakan pembelaan berupa protes advokat itu dicap sebagai hinaan terhadap pengadilan dalam perkara H.R Dharsono yang didakwa atas tindakan subversi. Adnan Buyung Nasutian dianggap membuat kegaduhan di pengadilan dan mengakibatkan advokat itu menerima teguran, bahkan pada proses selanjutnya Dewan Kehormatan IKADIN telah menyatakan perbuatan advokat itu telah melanggar kode etik advokat. Menurut Penulis sudah dengan amat jelas melanggar ketentuan yang tercantum dalam Kode Etik Advokat. Secara spesifik, yaitu pada Pasal 3 Huruf h, yang menyatakan bahwa kesopanan seorang advokat harus dijaga, kepada siapapun dan pihak manapun dengan tetap memertahankan hak dan martabat advokat.

Bahkan dalam sumpah menjadi Advokat, seperti yang tercantum pada Pasal 4 Angka 2 Poin ke-5 Undang-Undang Nomor 18 Tahun 2003 tentang Advokat, dinyatakan jelas mereka bersumpah "bahwa saya akan menjaga tingkah laku saya dan akan menjalankan kewajiban saya sesuai dengan kehormatan, martabat, dan tanggungjawab saya sebagai Advokat.'Tak hanya itu, pada Pasal 6 Undang-Undang Nomor 18 Tahun 2003 tentang Advokat, terutama pada Pasal 6 Huruf b, c, d, e, dan juga f juga kemudian menyoroti perilaku Adnan Buyung Nasutian yang sangatlah tidak patut, yaitu : Advokat dapat dikenai tindakan dengan alasan :

a. melakukan pelanggaran terhadap peraturan perundang-undangan dan atau perbuatan tercela;

b. bersikap, bertingkah laku, bertutur kata, atau mengeluarkan pernyataan yang menunjukkan sikap tidak hormat terhadap hukum, peraturan perundang-undangan, atau pengadilan;

c. melanggar sumpah/janji Advokat dan/atau kode etik profesi Advokat.

d. berbuat atau bertingkah laku yang tidak patut terhadap lawan atau rekan seprofesinya;

e. mengabaikan atau menelantarkan kepentingan kliennya;

f. berbuat hal-hal yang bertentangan dengan kewajiban, kehormatan, atau harkat dan martabat profesinya;

Selain itu terkait dengan perbuatan Adnan Buyung Nasution, dapat dikenakan sanksi berupa pemberian sanksi kode etik oleh Dewab Kehormatan Organisasi Advokat sesuai dengan kode etik profesi bahkan terancam terkena pemberhentian sementara menjadi advokat. ${ }^{16}$

16 Pasal 6 Undang-Undang Nomor 18 Tahun 2003 tentang Advokat (Lembaran Negara Republik Indonesia Tahun 2003 Nomor 49, Tambahan Lembaran Negara Republik Indonesia Nomor 4288) 
Fungsi dari diadakannya sistem peradilan pidana yaitu untuk memcahkan tiap masalah kejahatan yang berpotensi mengacau ketertiban dan memberi ancaman terhadap rasa aman masyarakat, sebagai pengendali kejahatan yang diupayakan masyarakat supaya ada pada batasan-batasan yang bisa diterima. Peradilan juga mengatasi kejahatan dengan peyerahan pelaku pada pihak pengadilan supaya timbul efek jera serta membuat orang yang hendak melakukan kriminalitas takut dan berpikir berulang kali sebelum bertindak. ${ }^{17}$

Sistem perdilan pidana bisa memiliki sifat fisik dengan maksud sinkronissi struktural dengan artian selarasnya mekanisme tata laksana peradilan pidana, bisa juga memiliki sifat substansial atas hubungannya dengan hukum positif yang ada, bisa juga memiliki sifat kultural, yang berarti penghayatan, pandangan, fundamen dan sikap yang menjadi dasar emplementasi sistem peradilan pidana yang inklusif, yang berlandaskan kesesuaian antara sistem peradilan pidana dengan ruang lingkup dan maknanya, sebagaimana diungkapkan oleh Muladi. ${ }^{18}$

Dalam struktur untuk menegakkan hukum pidana materil Sistem Peradilan Pidana yang Terpadu (SPPT) adalah unsur yang sangat penting. ${ }^{19}$ Ditinjau dari berbagai sisi emplementasi sistem peradilan pidana masih mempunyai banyak kekurangan. Satu dari sekian kekurangan itu sumbernya dari sistem peradilan yang tak mendapat dukungan penuh dari perangkat hukum positif sehingga tidak tercipta akuntabilitas serta transparasi sistem. Tidak hanya sampai di situ, sekian kekurangan yang ada juga berpengaruh terhadap tak terwujudnya tujuan sistem peradilan pidana. Sampai pada titik tertentu menjadi penghambat dalam mengendalikan kejahatan, seperti yang dikatakan Mardjono Reksodiputro, pada dasarnya sistem peradilan pidana adalah pengendalian kejahatan yang diupayakan oleh masyarakat supaya kejahatan masih berada pada batas yang dapat ditolerir. $^{20}$

Sesungguhnya, sangat diperlukan pengaturan tersendiri tentang perilaku tercela Advokat dalam persidangan yang bukan hanya semisal kejadian ini ada dalam KUHP saja, seperti pengajuan yang dilakukan oleh Ikatan Hakim Indonesia (IKAHI) kepada pihak legislatif terkait aturan-aturan tentang perlindungan hukum bagi hakim. Akan tetapi pihak legislatif belum mennaggapi, dan hal ini dimungkinkan karena apabila hal tersebut benar-benar diterapkan, yaitu perlindungan terhadap lembaga yudikatif, akan memunculkan masalah dikarenakan terlalu kebalnya perlindungan.

Terkait urgensi pengaturan perilaku tercela advokat dalam persidangan yaitu dampak yang ditimbulkan atas tindakan tercela advokat dalam persidangan di Indonesia yakni kerancuan keadilan serta kepastian hukum. Tujuan dari kepastian hukum yaitu

${ }^{17}$ Abdussalam dan DPM Sitompul, Sistem Peradilan Pidana, Restu Agung, Jakarta, 2007. hlm. 4

${ }^{18}$ Muladi, Kapita Selekta Sistem Peradilan Pidana, Undip, Semarang, 1995. hlm.13.

${ }^{19}$ Sidik Sunaryo, Kapita Selekta Sistem Peradilan Pidana, UMM Press, Malang, 2005. hlm. 2.

20 Mardjono Reksodiputro, Kriminologi dan Sistem Peradilan Pidana, Pusat Pelayanan Keadilan dan Pengabdian Hukum, Universitas Sumatera Utara, 1994. hlm. 140. 
ketentraman dan keamanan di lingkungan masyarakat, sehingga aturan-aturan serta kaidah-kaidah yang berlaku umum yang dibuat harus dilaksanakan dengan tegas. Hal ini tentunya dimulai dengan mengetahui tiap kaidah hukum dengan yakin. Kepastian hukum maksud hakikat atau simpelnya yaitu perilaku individu maupun kelompok tidak keluar dari batasan atau jalur yanng telah ditetapkan oleh aturan hukum. Kemudian dalam upaya mencapai kepastian hukum tersebut dibagi menjadi tiga asas yaitu kepastian hukum dari unsur peraturan perundang-undangan, lembaga dan pranata hukum, yang diemplementasikan melalui putusan-putusan lembaga. Syarat kepastian hukum sendiri yaitu kejelasan perundang-undangan dan dan hukum dan tidak ambigu.

Kejelasan peraturan yang menjadi asas tegaknya hukum yang efektif serta efisien sangat diperlukan, terkait kriminalisasi tindakan-tindakan pelecehan pengadilan dan hakim memang diperlukan, mengingat wibawa sebuah pengadilan harus tetap kuat, dan terwujudnya hal tersebut tentu harus lewat kejelasan prosedur dan aturan. Aturan mengenai tentang perilaku tercela Advokat dalam persidangan yang berlaku sampai saat ini, berupa aturan tersirat dalam KUHP. Aturan-aturan khusus sangatlah dibutuhkan, sebagaimana kita ketahui tindakan tercela ini semakin meluas sedangkan wibawa pengadilan harus tetap dijaga. Dalam hal ini hukum berperan dalam penjaminan berubahnya aturan secara teratur.

Ini berarti bahwa hukum perlu diperhatikan dalam membangun negara serta sebagai media membaharui masyarakat. Hukum memiliki banyak aspek dari kaidahkaidah sampai pada proses, sehingga hukum yang berkenaan dengan pembangunan hukum bukan dengan hukum materil saja, tapi juga hukum formil. Penelitian ini memunculkan hasil bahwa kebutuhan masyarakat perlu diperhatikan saat membaharui hukum. Dalam usaha menegakkan hukum, inilaah saatnya indonesia mempunyai aturan terkait perilaku tercela Advokat dalam persidangan secara khusus, karena hal ini bukan hanya untuk hakim sendiri namun juga sesuai apa yang dibutuhkan masyarakat. Mengingat semakin meluasnya tindakan yang dapat dikategorikan sebagai Contempt of Court yaitu segala tindakan maupun perbuatan yang pada prinsipnya mengganggu keselamatan, ketenangan psikis maupun fisik, diperlukan pengadaan aturan tentang perilaku tercela Advokat dalam persidangan secara khusus selaras dengan meluasnya Contempt of Court yang berpengaruh pada keselamatan, ketenangan psikis maupun fisik, dikarenakan memang berupa tindak pidana khusus, dalam arti kata tidak terintegrasi dalam KUHP.

Intinya adalah advokat harus menjunjung tinggi serta mematuhi seluruh konten dari kode etik, dan jika tak mematuhi tentu saja seorang advokat dikatakan melanggar kode etik advokat. Terkait batas tanggungjawab hukum dan etis perilaku tercela yang dilakukan Advokat dalam persidangan terdapat dalam Kode Etik Advokat yang telah secara jelas mengatur terkait sanksi-sanksi yang dapat dijatuhkan, apabila terjadi pelanggaran terhadap Kode Etik Advokat, tepatnya dalam Pasal 16 :

a. Hukuman yang diberikan dalam keputusan dapat berupa:

1) Peringatan biasa.

2) Peringatan keras 
3) Pemberhentian sementara untuk waktu tertentu

4) Pemecatan dari keanggotaan organisasi profesi.

b. Dengan pertimbangan atas berat atau ringannya sifat pelanggaran Kode Etik Advokat dapat dikenakan sanksi:

1) Peringatan biasa bilamana sifat pelanggarannya tidak berat

2) Peringatan keras bilamana pelanggarannya berat atau karena mengulangi kembali melanggar kode etik dan atau tidak mengindahkan sanksi peringatan yang pernah diberikan

3) Pemberhentian sementara untuk waktu tertentu bilamana sifat pelanggarannya berat, tidak mengindahkan dan tidak menghormati ketentuan kode etik atau bilamana setelah mendapat sanksi berupa peringatan keras masih mengulangi melakukan pelanggaran kode etik.

4) Pemecatan dari keanggotaan organisasi profesi bilamana dilakukan pelanggaran kode etik dengan maksud dan tujuan merusak citra serta martabat kehormatan profesi Advokat yang wajib dijunjung tinggi sebagai profesi yang mulia dan terhormat.

c. Pemberian sanksi pemberhentian sementara untuk waktu tertentu harus diikuti larangan untuk menjalankan profesi advokat diluar maupun dimuka pengadilan.

Penyempaian laporan terkait pihak yang terkena sanksi dan diberhentikan, baik sementara maupun dipecat dari anggota, ditujukan pada Mahkamah Agung sebagai informasi dan catatan dalam daftar advokat. Saat melaksanakan tugasnya sebagai seorang advokat dengan tujuan baik yakni membela klien dalam sidang maka dari aspek pidana atau perdata tak bisa dilakukan penuntutan, sebagaimana dijelaskan dalam aturan Pasal 16 UU tahun 2003 No. 18 tentang advokat dan kemudian didukung oleh Pasal 7 huruf g Kode Etik Advokat. Pada dasarnya kedua pasal tersebut memberikan hak perlindungan untuk advokat dalam bertugas, akan tetapi tetap harus berdasarkan batasan-batasan yang telah ditentukan, yang sesuai dengan Undang-Undang dan kode etik advokat.

Batasan dalam menjalankan profesi bagi advokat telah tertuang dalam Kode Etik Advokat Indonesia yang disepakati oleh sekurang-kurangnya tujuh organisasi advokat dan disahkan pada tanggal 23 Mei 2002. Kode etik advokat adalah kewajiban-kewajiban yang oleh para advokat dibebankan kepada dirinya sendiri. ${ }^{21}$ Pemberlakuan kode etik bersama ini dilakukan di bawah payung Komite Kerja Advokat Indonesia (KKAI). Sebelum adanya Kode Etik Advokat Indonesia, ketujuh organisasi advokat tersebut sudah memiliki kode etik masing-masing. Apabila dilihat dari substansinya, dapat dikatakan bahwa Kode Etik Advokat Indonesia merupakan adopsi dari kode etik profesi advokat yang telah ada sebelumnya, meskipun ada beberapa perbedaan tetapi tidak terlalu signifikan. Halhal umum yang terdapat dalam kode etik ini adalah mengenai kepribadian advokat, hubungan dengan teman sejawat, rekan sejawat asing, hubungan dengan klien,

${ }^{21}$ E. Sumaryono, , 1995, Op.Cit. hlm. 155. 
cara bertindak dalam menangani perkara, pelaksanaan kode etik, kedudukan dan peran Dewan Kehormatan, serta ketentuan-ketentuan lain. ${ }^{22}$

Perilaku tercela dalam profesi advokat berkaitan erat dengan hak imunitas atau kekebalan hukum yang melekat pada profesi ini. Hak imunitas adalah kebebasan advokat untuk melakukan atau tidak melakukan setiap tindakan dan mengeluarkan atau tidak mengeluarkan pendapat, keterangan, atau dokumen kepada siapapun dalam menjalankan tugas profesinya sehingga karenanya dia tidak dapat dihukum sebagai konsekuensi dari pelaksanaan tugasnya tersebut. Kebebasan artinya tidak dibawah tekanan, ancaman, hambatan, ketakutan atau perlakuan yang merendahkan harkat dan martabat profesi advokat. Lebih lanjut dalam Kode Etik Advokat Indonesia dikatakan bahwa kebebasan advokat untuk mengeluarkan pernyataan dalam sidang pengadilan dikemukakan secara proporsional dan tidak berkelebihan. ${ }^{23}$

Perilaku tercela dalam persidangan termasuk ke dalam suatu bentuk pelanggaran Kode Etik Advokat, sehingga dapat disampaikan pengaduan ke Dewan Kehormatan. Dewan Kehormatan adalah lembaga atau badan yang dibentuk oleh organisasi profesi Advokat yang berfungsi dan berkewenangan mengawasi pelaksanaan Kode Etik Advokat Indonesia sebagaimana mestinya oleh Advokat dan berhak menerima dan memeriksa pengaduan terhadap seorang Advokat yang dianggap melanggar Kode Etik Advokat. ${ }^{24}$ Dewan Kehormatan yang memiliki wewenang untuk memeriksa dan mengadili perkara pelanggaran Kode Etik yang dilakukan oleh Advokat.

\section{Penutup \\ Kesimpulan}

Di ranah hukum, peran advokat sangatlah penting, yaitu yang berkaitan dengan berperkara di hadapan pengadilan karena kemahiran serta wawsasan di bidang hukum sebagai bekal utamanya dan dapat diperhatikan peranan seorang advokat tentang memberikan jasa hukum pada klien. Berhubungan dengan pemberian jasa hukum peranan advokat tak terbatas pada satu tingkat saja, tapi bisa dimulai dari tingkat PN (pengadilan Negeri), Pengadilan Tinggi, bahkan sampai tingkat Mahkamah Agung. Terkait batas tanggung jawab hukum dan etis perilaku tercela yang dilakukan Advokat dalam persidangan terdapat dalam Kode Etik Advokat yang telah secara jelas mengatur terkait sanksi-sanksi yang dapat dijatuhkan, apabila terjadi pelanggaran terhadap Kode Etik Advokat, tepatnya dalam Pasal 16.

\section{Saran}

${ }^{22}$ Binziad Kadafi, et.al., Advokat Indonesia Mencari Legitimasi: Studi tentang Tanggung Jawab Profesi Hukum di Indonesia, cet. 3, (Jakarta: Pusat Studi Hukum dan Kebijakan Indonesia, 2002), hlm. 83-93.

${ }^{23}$ Kode Etik Advokat Indonesia, Pasal 7 butir g.

${ }^{24}$ Ibid., Pasal 1 butir e. 
Kekhususan serta kejelasan hukum sangat dibutuhkan ada atau tidaknya, terutama yang berkenaan dengan perilaku tercela dalam persidangan, jadi kehampaan hukum tak akan terjadi meskipun sebenarnya juga telah diatur dalam KUHP terkait aturan tentang contempt of court, namun aturan yang ada tersebut sifatnya masih global.

Hendaknya para pencari keadilan harus memiliki kesadaran hukum, harus dapat mengindahkan tata tertib di persidangan sehingga terwujud kedamaian dan ketertiban serta memperlancar proses persidangan dan Bagi advokat sebaiknya dapat bersikap profesional dalam menjalankan tugasnya.

\section{Daftar Pustaka}

Abdussalam dan DPM Sitompul, Sistem Peradilan Pidana, Jakarta: Restu Agung, 2007.

Andi Hamzah, Hukum Acara Pidana Indonesia, Jakarta: Sinar Grafika, 2004.

Binziad Kadafi, et.al., Advokat Indonesia Mencari Legitimasi: Studi tentang Tanggung Jawab Profesi Hukum di Indonesia, cet. 3, Jakarta: Pusat Studi Hukum dan Kebijakan Indonesia, 2002

Denny Kailimang, Mantapkan Persatuan dan Profesionalisme Advokat Sebagai Penegak Hukum dan Profesi Terhormat, Makalah, disampaikan pada Rakernas XII AAI, Pontianak, 18-19 Mei 2007.

E. Sumaryono, Etika Profesi Hukum: Norma-Norma Bagi Penegak Hukum, cet. Yogyakarta: Kanisius, 1995

Goble, Mazhab Ketiga, Psikologi Humanistik Abraham Maslow, Yogyakarta: Kanisius, 1987

Kode Etik Advokat.

Majalah Tempo, Maret 1986.

Mardjono Reksodiputro, Kriminologi dan Sistem Peradilan Pidana, Pusat Pelayanan Keadilan dan Pengabdian Hukum, Medan: Universitas Sumatera Utara, 1994.

Muladi, Kapita Selekta Sistem Peradilan Pidana, Semarang: Undip, 1995.

Ronny Hantijo Soemitro, Metode Penelitian dan Jurimetri, Jakarta: Penerbit Ghalia Indonesia, 1990.

Sidik Sunaryo, Kapita Selekta Sistem Peradilan Pidana, Malang: UMM Press, 2005.

Sjachran Basah, Mengenal Peradilan di Indonesia, Jakarta: Raja Grafindo Persada, 1995

Soejono, Soekanto, Pengantar Penelitian Hukum (Jakarta, 2007).

Syaputra, M.Y.A.,"Penafsiran Hukum oleh Hakim Mahkamah Konstitusi, Mercatoria", 4 (2): 72-85 Tahun 2011.

Undang-Undang Nomor 18 Tahun 2003 tentang Advokat (Lembaran Negara Republik Indonesia Tahun 2003 Nomor 49, Tambahan Lembaran Negara Republik Indonesia Nomor 4288). 